\title{
'Belonging before believing': Some missiological implications of membership and belonging in a Christian community
}

\begin{tabular}{|c|c|}
\hline $\begin{array}{l}\text { Authors: } \\
\text { Mario Weyers } \\
\text { Willem Saaym }\end{array}$ & $\mathrm{an}^{3}$ \\
\hline $\begin{array}{l}\text { Affiliations: } \\
{ }^{1} \text { Unit for Refor } \\
\text { North-West U } \\
\text { South Africa }\end{array}$ & $\begin{array}{l}\text { med Theology, } \\
\text { niversity, }\end{array}$ \\
\hline $\begin{array}{l}{ }^{2} \text { Department } \\
\text { Theology, Evar } \\
\text { Theological Fa } \\
\text { Belgium }\end{array}$ & $\begin{array}{l}\text { Practical } \\
\text { gelical } \\
\text { culty, Leuven, }\end{array}$ \\
\hline $\begin{array}{l}{ }^{3} \text { Department } \\
\text { University of S } \\
\text { South Africa }\end{array}$ & $\begin{array}{l}\text { Missiology, } \\
\text { outh Africa, }\end{array}$ \\
\hline $\begin{array}{l}\text { Corresponden } \\
\text { Mario Weyers }\end{array}$ & ce to: \\
\hline $\begin{array}{l}\text { Email: } \\
\text { weyers@eci.cc }\end{array}$ & \\
\hline $\begin{array}{l}\text { Postal address } \\
\text { PO Box } 6987, \\
\text { South Africa }\end{array}$ & Secunda 2302, \\
\hline $\begin{array}{l}\text { Dates: } \\
\text { Received: } 04 \mathrm{~F} \\
\text { Accepted: } 11 \mathrm{~J} \\
\text { Published: } 31\end{array}$ & $\begin{array}{l}\text { eb. } 2013 \\
\text { une } 2013 \\
\text { July } 2013\end{array}$ \\
\hline $\begin{array}{l}\text { How to cite th } \\
\text { Weyers, M. \& } \\
\text { W., 2013, '“Be } \\
\text { before believir } \\
\text { missiological } \\
\text { membership a } \\
\text { in a Christian } \\
\text { Verbum et Ecc } \\
\# 834,8 \text { pages. } \\
\text { org/10.4102/ }\end{array}$ & $\begin{array}{l}\text { is article: } \\
\text { Saayman, } \\
\text { longing } \\
\text { ng": Some } \\
\text { mplications of } \\
\text { nd belonging } \\
\text { community', } \\
\text { lesia 34(1), Art. } \\
\text { http://dx.doi. } \\
\text { e.v34i1.834 }\end{array}$ \\
\hline $\begin{array}{l}\text { Copyright: } \\
\text { (C) 2013. The A } \\
\text { Licensee: AOS } \\
\text { OpenJournals. } \\
\text { is licensed unc } \\
\text { Creative Comn } \\
\text { Attribution Lic }\end{array}$ & $\begin{array}{l}\text { uthors. } \\
\text { IS } \\
\text { This work } \\
\text { ler the } \\
\text { nons } \\
\text { ense. }\end{array}$ \\
\hline Read online: & \\
\hline 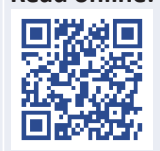 & $\begin{array}{l}\text { Scan this QR } \\
\text { code with your } \\
\text { smart phone or } \\
\text { mobile device } \\
\text { to read online. }\end{array}$ \\
\hline
\end{tabular}

In the final stages of the modern period the power of hegemonic ideologies is coming to an end as people identify less with grand ideologies and more with subcultures related to technology and social and economic networks of different kinds. The post-Christendom phase has begun and is radically challenging Christendom notions of membership and ministry. We have to assume that in a post-Christendom society, the familiarity with Christian concepts will fade as the decline of Christendom has meant that Christian discourse has been losing its status as a lingua franca. It is therefore important that the church will anticipate longer journeys towards faith and not move on to disciple new converts too quickly. Post-Christendom evangelisation will consequently take longer, start further back and move more slowly. For these reasons the authors propose that the question of standards for membership be reconsidered where churches are planted in postmodern contexts. They propose that the old order of 'believing before belonging' be replaced by 'belonging before believing'.

\section{Introduction}

In this article we are going to enquire into various processes and practices determining membership in a Christian community, parish or congregation. We are interested especially in missiological implications (in the general area of church planting) in a new era characterised by a postmodern paradigm (Bosch 1991). In order to do this, we have to start with a brief overview of some historical practices in this regard. In the earliest practices of catechesis (understood here as the process of preparing for membership of a Christian community) the early church envisioned that seekers would become inquirers. These inquirers were brought by a sponsor to the elders of the congregation. The elders had to discern the inquirer's spiritual motives. In some cases, these inquirers were disqualified because of their lifestyle or a profession that seemed incompatible with membership of the Christian community. If accepted by the elders these inquirers did not become members immediately, but rather catechumens. Catechumens were regarded as Christians 'in the process of becoming', but not yet counted fully amongst the faithful (Packer \& Parret 2010:54-55). Catechumens could participate in the service and ministry of the Word, but could not partake of the table (the Eucharist or Lord's Supper):

This dismissal [of the catechumens from the service during the Eucharist] was marked by a formal closing of the doors - recalling God's closing of the door on Noah's ark - thus reminding the catechumens that they were not yet truly among the saved. (ibid.:54)

In the final stages of training, catechumens were prepared to receive baptism, regarded as the rite to be acknowledged as giving these former inquirers full membership of the church. So no one who was not a recognised member could participate fully in Christian worship without having passed through formal training for membership. And no one could be baptised who had not been prepared through catechesis. Before becoming a member, therefore, one had to go through a prescribed process of teaching and induction - a process we would like to describe as believing before belonging.

Although it is undoubtedly a generalisation and simplification of a complex process, for the purposes of our article we would state that this remained the dominant practice, also in the later Constantinian church (cf. Weyers 2012 passim), and that it remained in place until the beginning of the period of modern Western Christian missionary work (around the 16th-17th century). The encounter between European missionaries and African peoples deeply influenced some Christian practices in an intercultural encounter for which both sides were totally unprepared. In Europe, where the church was in a dominant position, every citizen was generally considered to be a civilised (potential) member of the Christian church on the basis of their baptism and catechism. But what to do with 'uncivilised unbelievers', as African people were considered to be? The main motivation for mission was, after all, conversion of 'the heathens', and this implied 
that they had to become church members. The nature of early mission in the 16th century was mostly exploratory in nature, with no provision for the long period necessary to put new 'seekers' through the protracted process of catechism which customarily preceded membership in Europe. The first Christian missionary in Southern Africa, the Roman Catholic Father Gonzalo da Silveira, landed in Sofala (Portuguese East Africa) on the East Coast in 1560 (Du Plessis 1911). Within 7 weeks after his arrival at Gamba (near Inhambane), he baptised more than 400 people (ibid.). One can only think that it was the context which brought about this radical change in accepted practice: time was of the essence, and 'heathens' had to be saved.

The example set by Da Silveira established the custom followed by most early European missionaries to Southern Africa, Roman Catholic and Protestant alike. In the Cape Colony, though, history developed differently. With the Dutch East India Company in charge of the Colony, the Netherlands Dutch Reformed Church was to all intents and purposes a 'state church'. This church valued Reformed doctrine very highly, and this required proper training of catechumens ${ }^{1}$. The dominant European pattern therefore remained in place, so a set period of catechesis remained a requirement for full membership - one had to 'believe before one could belong'. Gradually this established road to membership in the Christian church also re-established itself in the other mainline mission churches, so that 'believing before belonging' also became the established pattern in Southern African Christianity. The question we wish to address in this article is whether this is still the best pattern to follow. We doubt very much whether one should still maintain this practice in our present era, as we agree with Bosch (1991) that we are experiencing a paradigm shift in the theology and practice of mission. ${ }^{2}$ Such a period requires creative solutions to new problems, which is why we wish to explore whether one could and should rather follow a pattern of 'belonging before believing'. We now turn our attention to this proposal.

\section{The contemporary (postmodern) shift from believing towards belonging}

Fensham (1990), in his doctoral thesis 'Missiology for the future - A missiology in the light of the emerging systemic paradigm', is concerned with the future ministry of the church. He is of the opinion that we need a new vision as Christians to deal with the future in a creative way. $\mathrm{He}$ emphasises the importance of and the need for a way of thinking that is wider than simply the institutional church. Ebeling (2009:145) shares his concern, and is of the opinion

1.Early in the 18th century, for example, Rev $F$. le Boucq criticised some of his fellow ministers for baptising slave converts far too easily (i.e. without 'proper' catechetical instruction - Saayman 2007:24)

2.We are not going to argue the case for or against the idea of a paradigm shift here We refer readers in this regard to Bosch (1991:1-14 181-189). We are aware of the fact that objections can be brought againt Bosch's utilisation of the concept (cf. Pill 1990), and do nan be brought against Bosch's utilisation of the concept (cf. Pillay 1990), and do not necessarily agree with Bosch in every respect. For the sake of our argument in this article, though, we find enough common ground with Bosch to accept his main argument. that one cannot refer people who are 'converted on the streets' without reservations to any of the existing churches, because existing churches are not constituted in such a way that they can absorb outsiders easily. This concern arises from the fact that traditional patterns of living are changed and shaped by the future and that the enduring institutions of society are therefore threatened if they do not take action in constantly adapting to the ever changing challenge of the future:

It is [actually] not [simply] adapting, but rather that religious institutions that do not adapt to the shifts that are taking place in religious perception due to rapid change will dwindle and eventually lose their relevance. (Fensham 1990:126)

J.B. Arthur (2001) is a missionary of the Church of Scotland. In his book The real Church he confirms that the church as such finds itself in a problematic situation, because at least a part of the church needs to be incarnated in the culture of secularism without sacrificing the church's historical identity. According to his experience, this is precisely the challenge of being relevant. Why is this so? The church in every age seeks to redefine itself. This produces tension in the life of the church, for if it is always changing then it can logically change its essential nature for something else. Then again, if the church does not change, it will certainly fail in its effort to reach the people and will become irrelevant. It is also important to point out at this stage that it is, according to Ebeling (2009:152), not simply a renewal of present churches we should be searching for: we need completely new 'types' of churches or congregations to minister to the present context. In his words, the central issue is not renewal, but a new structure.

In Why we love the church De Young and Kluck (2009) provide four reasons why postmodern people are disillusioned with institutionalised religion. People find a lack of missional ${ }^{3}$ concern in institutionalised religion. Members find their congregation not growing in the sense that there are no new converts or baptisms taking place and that young people are not remaining in the church after high school. Many insiders, as well as outsiders, have personal objections towards the institutionalised church. The church in the eyes of many harbours and indeed is preoccupied with antiwoman and antigay issues. They find the church legalistic, oppressive and hurtful. Many experience the institutionalised church as corrupted beyond recognition and blame this on historical grounds. Some blame Constantine and the evils of Christendom (cf. Weyers 2012). In the 4th place there is a biblical and theological critique. Many no longer consider it important to participate in an institutionalised church service as it is believed that all one needs for proper worship of Christ are two or three people with an intent to be with the Lord, wherever they decide to meet.

In his new publication, Delen en vermeniguuldigen, Lukasse (2009) describes the radical change in religious perception that has taken shape in history. In Victorian times the church was shaped in the linear form of behaving - belonging - believing.

3.We use the terms missional and missionary interchangeably, as we consider the difference between the two to be a question of terminology, not content - see Saayman (2010). 
In the time of modernism it was shaped in the linear form of believing - belonging - behaving. Now, in the postmodern age, it is shaped in the linear form of belonging - behaving - believing. No longer is it religious values or evangelical beliefs which attract today's postmodern people to put their faith in Christ, but rather unconditional acceptance into spiritual and faith communities. ${ }^{4}$

It thus seems that theologians do agree that the traditional ecclesia is challenged in this post-Christendom and postmodern age to transform into a new praxis of ministry in order to relate effectively to people's religious needs. For some this is a positive challenge whereby the ecclesia can re-establish its relevance in the ministry to seekers in a postmodern age. These theologians believe that the transformation should imply that the leadership of Christian communities needs a biblical foundation from where they can move beyond the matrix of modernity; secondly, leaders should have enough confidence in the biblical text to relate positively to all the present cultural needs in society (the typical nexus of 'danger and opportunity' that Bosch [1991:1-3] writes about). This requires that all types of cultural phenomena should be welcomed into God's presence without insisting ahead of time on a primary belief in the Gospel of Christ which will automatically disqualify people's sincere cultural customs and beliefs:

Instead of being fixated on whether people are saved or not ... we should see conversion as a process, and our part in evangelism is to help encourage people in that process. When we try to pin people down into exact categories ... we actually buy into modernity's emphasis to try to have everything understood and spelled out [beforehand]. (McLaren in Smith 2005:58)

There are, indeed, churches that are aware of this new requirement, and therefore attempt to create 'seekerfriendly' or 'strangerfriendly' communities of Christians. However, in an interview on 20 December 2008, Johannes Reimer pointed out a problem with this approach: most of these churches and communities have programmes which are basically aimed at integrating new members into the dominant Christian culture as rapidly as possible. In other words, the basic presupposition is that these seekers and strangers will be helped to 'get rid of' their 'misunderstandings' about the 'real' practice of Christian belief as rapidly as possible, so that they can be easily 'integrated' into the dominant practice. In the long run, this type of approach therefore does not truly advance the 'multicultural community building' which Reimer proposes. It is against this background that we wish to propose our own approach of developing a process of integrating people into full membership of the Christian community on the basis of belonging before believing.

\section{A brief reference to the earthly ministry of Jesus}

In the brief earthly ministry of Jesus he held to his full identification with the human situation, but at the same

4. Readers could argue that ascribing an attractional value to the church is a typically modern phenomenon, whilst we are arguing in favour of a postmodern approach. Our response would be to follow Bosch (1991:181-189) in his argument that paradigm shifts (from modern to postmodern) are not demarcated by neat boundaries: they continue to overlap for quite some time. time did not compromise on his commitment to God's requirements. This was the source inspiring his extraordinary mission and was the authoritative model for his disciples. The teaching of Jesus is the real core of Christianity, as the simple teaching of Jesus was not a dogmatic system, but comprises basic convictions, principles and injunctions as expressions of religious consciousness. ${ }^{5}$

Jesus had different levels of following and support during his earthly ministry. There were the 12 disciples who could be recognised as insiders (Mk 3:13-19), who took part in Jesus' ministry and were strongly associated with him. Peter, James and John (Mk 3:16-17 and Lk 9:51-55) could be seen as the core group of insiders, having closer encounters with Jesus than the other nine and becoming the pillars of the newly founded Christian community in Jerusalem (Gl 2:9). In addition, the New Testament also mentions the seventy who were sent out by Jesus, the women of Luke 8:1-3 supporting Jesus on the road and the 120 mentioned by Luke in Acts 1:14-15. But then, there were many who could be labelled as outsiders. They followed Jesus' ministry and were constantly trying to be in his presence, seemingly without yet being completely convinced of his teaching and demands (Mt 4:25). It seems to us that Jesus had no problem carrying out his ministry amongst those who did not yet believe in him as Messiah, who belonged to the crowds that followed him from a distance (Mt 7:28).

This also seems to be the case in the Gospel of John (6:60, 66-67), where Jesus is explaining his mission to those outsiders that are following not from within but from a distance, and challenging and disciplining them to come to full belief. This is the case with Nicodemus in John 3:1-15 (see also Jn 7:50-52 and 19:39) and with Joseph of Arimathea in John 19:38. Jesus' ministry seems to be inclusive of outsiders in the sense that he does not mind if they follow from within the safety of the crowds; but it tends to become more significant for those who would follow him in faith after the Easter events.

In general one can also observe that the disciples' faith in Jesus was far from perfect. Often when it seems that the disciples were at last following from the inside, the Gospels reveal the opposite. Peter, who pledged that he would follow Christ from the inside and not forsake him even in the face of death and persecution, denied knowing Jesus - not once but three times, thus revealing a stance more in keeping with that of a total outsider (Jn 13:31-38 and 18:25-27). Thomas, another insider and one of the twelve, was not present when Jesus first revealed himself as the risen and glorified Christ to the disciples. When he was informed that Jesus had appeared to them, he was not convinced and needed proof (Jn 20: 24-29). On many occasions we find that the disciples who had followed Jesus from the inside prior to his death, reacting to his resurrection appearances as if they were total strangers. An example is the story of the two men on their way to

5. For a fuller discussion of our application and use of New Testament material, please see Weyers (2012:90-98, 109-130). We are not juxtaposing Jesus values against Christian values here, that would be a contradiction in terms. With Christian values Christian values here, that would be a contradiction in terms. With Christian values we are referring to ideologically and culturally determined dogmatic systems developed as integral dimension of the Constantinian system (Christendom). These often did not reflect the core values of the life and teaching of Jesus of Nazareth. 
Emmaus (Lk 24:13-35) that do not recognise Jesus himself as their companion. Filled with despair they left Jerusalem, as their hope for a Jewish redeemer who would redeem Israel (Lk 24:19-21) seemed lost. In verses 25 and 26 we find Jesus reacting strongly to their unbelief and helping them to identify anew with him as the risen Lord.

\section{A brief review of the ministry of the Holy Spirit}

We find in the New Testament that there is a profound change in the character of the disciples from their pre-Easter to their post-Easter experience. In the pre-Easter timeframe it becomes clear that the disciples belonged much more to Jesus' ministry than that they fully understood and supported his mission as the saving Son of God. Only after the resurrection of Christ from the grave and the outpouring of the Holy Spirit, do we find that the disciples have grown from not only belonging to a messianic movement, but believing in its founder as the promised Messiah.

In Matthew 16:21-23 we find that Peter is horrified at Jesus' explanation of his coming messianic suffering and its implications for the fate of his master. Peter cannot grasp that such a tragedy could be God's purpose. Jesus turns to face not only Peter, but the other disciples behind him, as they too need to learn from Peter's mistake. In Matthew 17:1-8 we find a similar story told by Matthew. The transfiguration story reveals Christ as the one who is to suffer as God's chosen Messiah. A subsidiary theme is that of the revelation of Jesus as the new Moses, suggested by several echoes of the account of Moses' meeting with God on the mountain in Exodus 24 and 34 and by the allusion to Deuteronomy 18:15. Peter's proposal to build shelters for Jesus and his august visitors is once again a misunderstanding of Jesus' mission, which is not to stay on the holy mountain but to go down to the Cross (cf. France 1990). In Acts 2:14-36, however, just after the outpouring of the Holy Spirit, we find Peter, with the other 11 , explaining that Jesus' death was a deliberate salvific plan of God and that the Cross confirms Jesus' messianic calling.

Interestingly enough, we find that Peter in Acts 2:14-36 is preaching a sermon on believing in Christ to more than 3000 people where he previously, before the Easter encounter, denied even knowing Christ (Jn 18:25-27). What made the difference in his character? It was the outpouring and assistance of the Holy Spirit after the resurrection of Christ.

In Luke 9:51-55 we read that James and John wanted to call fire from heaven to destroy a Samaritan village through which they and Jesus were passing to reach Jerusalem. They were searching for an overnight facility in the village for Jesus before continuing on their journey, but were unable to find any hospitality amongst the Samaritans. We read that Jesus rebuked James and John for turning to violence and they moved on to Jerusalem without stopping amongst the Samaritans. These two followers of Jesus did not fully understand that Jesus' kingdom was not of this world and that he came not to rebuke those that were not of a true Jewish background, but to seek and save those who were lost (cf. Nel 2010). One needs to keep in mind that for nationalistic Jews, Samaritans were considered to be worse than Gentiles due to the Samaritan defilement of the Jewish temple:

The Jewish reader of Luke's gospel would therefore fully understand the attitude of James and John, not however the reaction of Jesus. It is clear from the context that Jesus' conduct reflects an explicit and active denial of the law of retaliation and is, precisely as such, also a pointer toward a mission beyond Israel. (Bosch 1993:90)

In the post-Easter encounter of Peter and John in Samaria (Ac 8:14-17) we find the powerful intervention of the Holy Spirit. Previously, where the disciples wanted to call fire from heaven to destroy the Samaritans, we find in Acts that the apostles pray for the Spirit to come down on the Samaritans to bless and empower them. The apostles lay their hands on them and they receive the Holy Spirit.

In the pre-Easter context the disciples belonged to the following of Christ without fully comprehending what kind of Messiah Jesus would be. Their expectations of Jesus as Messiah differed. In the post-Easter encounter we find that because the disciples had encountered the risen Christ and had seen his glory they now finally not only believed, but wanted others (outsiders) to also come to faith. The Holy Spirit assisted in a dramatic church growth adventure. Firstly, the disciples discovered Jesus. Then they experienced curiosity as they engaged in following him. Their sense of belonging strengthened as they committed themselves to following Jesus, in spite of his teaching on the Cross and his death that they could not fully comprehend at the time. With the death of Jesus followed dissonance and insecurity in the disciples' commitment to Christ. With the outpouring of the Holy Spirit came believing in Jesus as the Son of God.

\section{The membership process in the historical narrative in Acts}

For the purposes of our argument it is necessary also to briefly review the historical narrative about the first congregation as described in the book of the acts of the Apostles. We are convinced that such a chronological review may provide useful material in a debate about church membership today. We find in the Book of Acts that Luke is explaining to believers how the Christian community of faith started by telling them the story of the beginning of the first community of believers in Jerusalem. With the miraculous birth of the first apostolic congregation in Jerusalem, as described in the Book of Acts, it seems unlikely that the apostles individually interviewed or examined each of the 3000 converts mentioned in Acts 2:41. Rather, it seems that on the basis of what Peter and the other apostles preached, the 3000 converts were admitted into the fellowship, and subsequently sat under the apostles' teaching (Ac 2:42a) to learn the important contents of the Gospel. It therefore follows that the Spirit is not only the agent of mission, but also the mark of those who eventually truly behave accordingly (Ac 2:44-46). Although this process does not so much describe the dichotomy between believing and belonging in essence, it reveals an important chronology whereby the aspect of belonging takes place before the event 
of actual content of believing is described. This opens up the possibility of a sequence where belonging before believing is acceptable in a context where teaching of and commitment to the gospel take place later. The process might be described as follows from the New King James Version:

- Admission to seekers (Ac 2:37-41) to belong to the Jesus movement: (Ac 2:41) Then those who gladly received his word were baptised. And the same day there were added about 3000 souls.

- Instruction on what followers of Jesus believe: (Ac 2:42) And they were continuing steadfastly in the apostles' doctrine, and in fellowship and in the breaking of the loaves, and in prayers.

- Proof of the fruit of the Spirit as a new behaviour sets in: (Ac 2:44-46) And all who believed were together and had all things common. And they sold their possessions and goods and distributed them to all, according as anyone had need. And continuing with one accord in the temple, and breaking bread from house to house, they shared food with gladness and simplicity of heart.

Of course, there is one important factor to keep in mind in the above argument. In the Book of Acts the Church in Jerusalem had just started out and did not as yet have a fixed set of ecclesiastical rules as to who might belong and who could upset its growing momentum. With the birth of the church in Jerusalem on Pentecost, it was merely a Jesus movement that would only much later develop into an ecclesiological institution. Therefore the above argument that the 3000 converts were simply welcomed into the circle of believers without any set of rules to verify their commitment must be understood against the background of the church in its initial birthing stage and not in its official ecclesiological role. Although Acts 2:41 is interesting in regards to the above it cannot simply be used without reserve to argue for belonging before believing, as the church evolved from a missionary movement to an ecclesiastic institution.

Many of the Gentiles who eventually became Christians had previously been proselytes or God-fearers, that is, people who initially were related to Israel, such as Gentiles of the synagogue who accepted the Gospel. In Luke 7:1-10 the centurion is a God-fearer who sends Jewish elders to speak to Jesus on his behalf; their testimony of the centurion seeks to gain a favour from Christ.

In Acts the term 'Gentiles' replaces the characteristic Gospel terms so frequently used for the poor and the outsider. Simply put, the outsiders in Acts become the Gentiles and it is significant to notice that Luke mentions Gentiles 43 times in Acts and builds his mission story with them in view (cf. Bosch 1991). Luke's description of the church in Acts has therefore a bipolar orientation referred to as 'inward' and 'outward' (cf. Bosch 1991:119). Firstly, it is a community which devotes itself to the formation of a basic inward ecclesiology which entails the teaching of the apostles, fellowship, the breaking of bread and prayer. Secondly, the community also has an outward missionary ecclesiology whereby it refuses to understand itself as a sectarian group. It is actively engaged in a mission to those not yet belonging to Christ and his church.
In his encounter with Cornelius in Acts 10:43 Peter makes the astonishing discovery that the Holy Spirit's vision is focused on a much broader covenant community, beyond those who come from a Jewish background. According to Luke's record, Jesus turns his back on the in-group mentality of his day (Bosch 1991:112) by challenging their 'ethic of election' and thus we find a Lucan narrative where there is room in the Christian church for rich and poor, Jew and Gentile, oppressor and oppressed. Apart from telling the story of outsiders who become followers of Jesus, Acts also relates the process of the faith community's journey to becoming inclusive and crosscultural.

In this narrative we see a process which we describe as a process of belonging before believing. ${ }^{6}$ We now turn our attention to a brief presentation of how we think such an approach to ministry and membership might be helpful today.

\section{Belonging before believing}

We have to begin our argument by pointing out that we base it on a very specific understanding of conversion. Saayman (1992) argues that conversion is often brought into the mission narrative prematurely. Furthermore, it is too often understood as a once-off event taking place momentarily. Orlando Costas (Stott 1980) describes conversion as an ongoing experience that is not a once-off experience, but rather many lifelong experiences implying ongoing life changes:

For the complexity of conversion does not lie in a fixed number of experiences but in the fact that it is a plunge into an ongoing adventure. Christian conversion is a journey into the mystery of the Kingdom of God which leads from one experience to another. Initiation in the journey of the Kingdom implies a plunge into an eschatological adventure where one is confronted with ever new decisions, turning points, fulfilments, and promises which will continue until the ultimate fulfilment of the Kingdom. (p. 182)

Saayman (2005) agrees with the above assessment, specifically on the subject of understanding the issue of conversion as an ongoing life process, thus countering the impression that in converting seekers from merely belonging to believing, the church only seems interested in numbers of 'converts', rather than in quality of life in a believing community. This is the more important aspect today as there seems to be a growing resistance against apologetic arguments in evangelising nonChristians, attempting to express belief simply on the basis of what is presented as a 'superior set of arguments' (Smith 2005:47). The subject of conversion can thus be introduced and forced on individuals too early in the missionary process, not allowing the necessary time to pass in which outsiders can find proof of the power of the Gospel in the lives of those claiming to follow Christ, simply through being allowed to belong.

We believe therefore that the New Testament does allow a generous space to those who first need to belong, before they are ready to fully believe, for the following four reasons:

6.Weyers (2012:98-108) presents a more extensive analysis of biblical material, also of terms such as 'god-fearers', et cetera. We refer readers to that analysis if a more extensive discussion of New Testament material is required. 
- Amongst post-Christian communities there is a growing insistence on first belonging before believing. This is necessary for postmodernists, for whom it is important to first have an opportunity to test whether the Christian community to whom they want to belong actually does practice what it professes to believe.

- Knowledge of Christianity and Christ's salvific mediation is rather limited amongst post-Christian communities that do not have a historic bond with the Christendom era. Post-Christian seekers need more time to get to know the Gospel and its implications before they want to react to it.

- 'Christian' culture (of the Constantinian, Christendom kind) seems strange to post-Christian communities, because people are becoming more ritually 'illiterate' in traditional Christian terms and are in need of experimental participation, which is a safer stance than immediate surrender to the 'Christian' way of belief.

- This is why it is important to provide space and room for questioning theology as true beliefs are formed in the cauldron of wrestling with Scripture in community: 'One of the past abuses of Scripture is the inability to allow people space and time to process beliefs' (Webber 2007:36).

Murray (2004:35) is of the opinion that post-Christendom churches will be 'messy communities' where the important issues of belonging, believing and behaving are to be seen as a process rather than a neatly integrated system as found in the Christendom age. We know that two common positions are alive and well in the post-Christendom context. The one is that some people do not belong to a church, but identify themselves as Christians and hold to those ecclesiological beliefs that are more or less consistent with those who do belong to a local congregation (being baptised, being buried from a church, etc.). The other is the one that is investigated in this research, where some participate in church liturgy and worship before they identify themselves as Christians or evangelical believers. It should be normal for local congregations that are finding themselves in the context of the latter group, to allow nonbelievers to interact with the life of the church (cf. 1 Cor 14:23 and Col 4:5) and Christians should be warm, loving and welcoming to those who are not yet committed.

As mentioned Murray (2004:13) is concerned with the second. He recognises that a new paradigm in evangelism has emerged since the 1990s whereby people are coming to faith by means of a journey rather than 'through a once off event'. Process conversions should be seen as equally valid for those who want to belong first and then believe. This new understanding needs to encourage churches to become more welcoming, hospitable, inclusive and patient before requiring assent to a belief system as commonly expressed in confessions of faith which signify church membership.

We have to assume that amongst post-Christians the familiarity with Christian concepts will fade, because the decline of Christendom has meant that Christianity has been losing its status as a religious lingua franca only fully understood by those who are professing Christians. It is therefore important that the church should anticipate longer journeys towards faith (in the sense of confessional assent) and not move on to disciplining new converts too quickly. Post-Christendom evangelisation will consequently take longer, start further back and move more slowly.

Thus it seems that we will gain ground missiologically in the post-Christendom phase by helping outsiders to belong before we require them to profess their faith in a confession. This will require innovative missionary ecclesiological responses such as centre-set churches.

\section{Centre-set churches}

The centre-set model characterises churches that encourage belonging before believing. They will have to promote so-called centre-set or core principles, namely those that strengthen institutional congregations that are willing and brave enough to engage incarnationally with the post-Christendom context. In the process they establish a missionary ecclesiology with open boundaries. These principles need to help seekers understand the Lordship of Christ, the salvation that is to be found in him, and the Biblical guidelines that teach us to maintain a true relationship with Jesus. This implies a true relationship with the Creator, other human beings, and the created environment.

Centre-set churches should be distinguished from boundedset churches. According to Murray (2004) Christendom as a civil religion (culture) in the past represented a bounded set of core principles, because it maintained control of institutional structures to ensure that everyone within its boundaries believed similarly and therefore behaved accordingly. The bounded-set church model sustained communities by clearly articulating beliefs, prescribing the preferred behaviour and acknowledging those who behaved accordingly. In our opinion this model is restrictive as it takes a stance from a survivalist position and does not position itself to be culturally attuned to play a missional role in the community. Secondly, there is not always a clear-cut understanding of where the boundaries should be operational. For some churches the boundary would include the entire national population sharing in a religious, social and cultural history and heritage. For those following a more evangelical conviction, the boundary would be demarcated by distinguishing between those who have a testimony and those who do not.

Centre-set churches should also be distinguished from fuzzy-set churches, which allow too much generous space, as those who want to belong could disbelieve many aspects of authentic Christianity and behave in ways corresponding with contemporary norms rather than with traditional evangelical expectations. This is possible as it is unclear where the boundaries are and whether they are truly functional. Although this model could be attractive to those who find bounded-set churches too oppressive, it is unstable. It can 
easily revert either to a bounded-set structure or develop into a dangerously unsustainable open-set model of being church.

The open-set model is naturally inclusive and appears to have a philosophy of 'anything goes'. This model could be extremely attractive to outsiders who do feel the need to belong spiritually, but are by no means prepared to follow a religious path of being discipled for Christ. This model does not advocate a decisive centre and therefore in the long run cannot foster sustainable community.

The centre-set model has distinctive features (Murray 2004):

- It has a definite centre as well as non-negotiable core convictions, rooted in the story of Jesus Christ.

- The centre represents the focal point, around which members of the community gather.

- Its core convictions shape its identity and separate it from other communities in a plural and contested environment.

- The church expends its energy on maintaining the core rather than patrolling the boundaries.

- Confidence in its core convictions helps the church to be inclusive, hospitable and open to those who are in need of belonging.

- Those who 'belong' are supported in moving closer to the centre, however near or far away they currently are in terms of belief.

Because centre-set churches can be as inclusive as openset churches, as relaxed as fuzzy-set churches and as committed to principles as the bounded-set churches, we want to recommend this model as suitable for the challenges facing our post-Christendom context: 'Centre-set churches encourage spiritual growth, theological investigation, intellectual honesty, receptivity to new ideas and new people, and a journeying image of understanding' (Murray 2004:30). Centre-set churches are formed by defining the centre. If the centre is communicated well in terms of the church's missional functions, its boundaries will emerge organically from within its ecclesiological activity. Centre-sets are not created by first drawing boundaries, but by establishing relationships with people related to or moving towards the centre, as well as with those who are not yet on that journey:

Churches with healthy centres are secure enough to welcome those who are exploring faith and searching for authenticity. They are relaxed, non-judgemental communities where questions, doubts, dissent and fears can be expressed and where ethical issues do not preclude acceptance. (Murray 2004:30)

On being church in the post-Christendom age, one has to think differently about what church is and how people become part of it: 'It is just as much a family to belong to, as it is a set of beliefs to adhere to' (McClung 2008:189). In the post-Christendom age we cannot work exclusively with the single notion that people come to faith in Jesus at a specific moment in the timeline of their life, through simply believing in a set of confessional doctrines. Rather it is also about getting to know and trust in Jesus through a journey from belonging to believing, with many stops and starts along the way. In other words, conversion is not either a huge crisis event or an ongoing process - it is both.

In our opinion, the route to go if one is serious about befriending lonely and alienated postmodern people is what is called the centre-set paradigm. The binding force is therefore the strong attraction emanating from the centre of an open community, not the clearly marked set of boundaries which force people to remain either outside or inside. ${ }^{7}$ The boundaries could be fuzzy in terms of who is really 'in' and who is 'out', but the central focal point is always clear: devotion and obedience to the person of Jesus Christ.

If we are truly implementing a missionary ecclesia amongst our postmodern neighbours and non-Christian friends, we will have to cope with 'messy' boundaries, just as in Jesus' ministry it was not always clear who was or was not yet a disciple of Jesus amongst his followers. In reality we have believers who do not seek, and seekers who do not yet believe. Thus if we can live with messy, unclear boundaries, together with a clear centre, we will have grasped the importance of making disciples.

\section{Conclusion}

We have found that the axioms of believing before belonging and belonging before believing do not necessarily have to be in conflict with each other. The former was presented as the only 'right' way in the Constantinian or Christendom era. In the present mainly post-Christendom or postmodern era, more of the church's energy in evangelisation has to be focussed on the challenge of adapting to the needs of those who want to belong but do not necessarily want to start out by subscribing to a specific set of dogmatic interpretations in a confession of faith. We have therefore found that a missionary ecclesiology that will assist seekers in their journey in the present context is one that understands the priority of allowing those who are in need of belonging before believing to experience a gracious space in the worship of the church for seekers. This approach will allow for a process phase during which those who at first only participate through belonging can eventually come to a heartfelt confession of faith.

\section{Acknowledgements Competing interests}

The authors declare that they have no financial or personal relationship(s) that may have inappropriately influenced them in writing this article.

\section{Authors' contributions}

The article is based on M.W.'s (North-West University) doctoral thesis (2012, University of South Africa), 'The nature of the church in some post-Christendom models and according to some authors in the New Testament: A comparative study with missiological implications'. W.S. (University of South Africa) was his supervisor.

7.In Ebeling's words (2009:152), postmodern people are looking for 'community, not congregations'. 


\section{References}

Arthur, J.B., 2001, The Real Church, Uzima Press, Nairobi. Bosch, D., 1991, Paradigm shifts in theology of mission, Orbis Books, New York. Bosch, D., 1993, Transforming Mission, Orbis Books, New York.

De Young, K. \& Kluck, T., 2009, Why we love the church?, Moody Publishers, Chicago. Du Plessis, J., 1911, A history of Christian missions in South Africa, Longman's Green, England.

Ebeling, R., 2009, 'Emerging church - Wiederbelebung alter Träume zwischen 1960 und 1980?', in R. Ebeling \& S. Meier (eds.), Missionale Theologie, Jahrbuch 2009, Gesellschaft für Bildung und Forschung in Europa E.V., n.p., Francke, Marburg.

Fensham, C.J., 1990, 'Missiology for the future: A Missiology in the light of the emerging systemic paradigm', unpublished doctoral thesis, University of South Africa, Pretoria.

France, R.T., 1990, Tyndale New Testament Commentaries, WB Eerdmans, Grand Rapids.

Lukasse, J., 2009, Delen en vermenigvuldigen - Een praktische handleiding voor stichten van nieuwe gemeenten in Europa, Johannes-multimedia, Nederland. PMid:19747265

McClung, F., 2008, You see bones, I see an army, Struik Christian Books, Cape Town. Murray, S., 2004, Church after Christendom, Paternoster Press, United Kingdom.

Nel, M.J., 2010, 'Lukas 10:1-16 as begronding van die kerk se sending in LukasHandelinge', Verbum et Ecclesia 31(1), n.p.
Packer, J. \& Parrett, G.A., 2010, Grounded in the Gospel-building believers the old fashioned Way, Baker Books, Grand Rapids, Michigan.

Pillay, G., 1990, 'Texts, paradigm and contexts: An examination of David Bosch's use of paradigms in the reading of Christian history', in J.N.J. Kritzinger \& W.A. Saayman (eds.), Mission in creative tension, pp. 109-123, S.A. Missiological Society, Pretoria.

Saayman, W.A., 1992, "If you were to die today, do you know for certain that you would go to heaven?" Reflections on conversion as primary aim of mission', Missionalia 22(3), 19-27.

Saayman, W.A., 2005, 'New Testament studies and Missiology in South Africa', Missionalia 33(2), 205-213.

Saayman, W.A., 2007, Being missionary being human: A review of Dutch Reformed Mission, Cluster Publications, Pietermaritzburg. PMid:17896874

Saayman, W.A., 2010, 'Missionary or missional? A study in terminology', Missionalia 38(1), 5-16.

Smith, R.S., 2005, Truth and the new kind of Christian, Crossway Books, Illinois.

Stott, J. (ed.), 1980, 'Conversion as a complex experience', in R.T. Coote \& J.R.W. Stott (eds.), Down to earth: Studies in Christianity and Culture n.p., WB Eerdmans, Grand Rapids.

Webber, R.E., 2007, Listening to the beliefs of emerging churches, Zondervan, Grand Rapids.

Weyers, M., 2012, The nature of the church in some post-Christendom models and according to some authors in the New Testament: A comparative study with missiological implications, Unisa, Pretoria. 